\title{
Knowledge and Practices of Meat Hygiene among Meat Handlers and Microbial Profile of Meat in the Jos Abattoir, Plateau State
}

\author{
Miner $\mathrm{CA}^{1}$, Agbo $\mathrm{HA}^{1}$, Dakhin $\mathrm{AP}^{1}$, $\mathrm{Udoh}^{2}$ \\ ${ }^{1}$ Department of Community Medicine, Faculty of Clinical Sciences, College of Health Sciences, \\ University of Jos. \\ ${ }^{2}$ Department of Community Medicine, Jos University Teaching Hospital. \\ Correspondence: Miner, Chundung A, chundungminer@yahoo.com, Phone: +2347037000880
}

\begin{abstract}
Background: Meat handling and sanitation practices can have resultant effects on the quality of meat sold to the public. The study aimed to determine the knowledge and practices of meat hygiene amongst meat handlers. It also sought to determine the microbial profile of meat sold in the Jos abattoir of Plateau State.

Methodology: It was a cross sectional study conducted among 128 butchers and meat handlers in the Jos abattoir selected by total population sampling technique. Data on knowledge and practice was collected using a semi-structured interviewer-administered questionnaire. Sampled meat products were analysed for bacterial load using Serial Dilution technique and bacterial pathogens identified by standard procedures. Epi Info statistical software was used for data analysis at a 95\% confidence limit.
\end{abstract}

Results: The mean age of respondents was $32.8 \pm 10.4$ years and all were males. A fair knowledge of meat hygiene was found among $55.5 \%$ of respondents while $8.6 \%$ were adjudged to have good meat hygiene practices. The mean bacterial load for sampled meat for sale was $2.5 \times 10^{3}$ $\pm 3.4 \mathrm{cfu} / \mathrm{ml}$. Main bacterial isolates identified were Escherichia coli, Pseudomonas spp and Enterobacter spp.

Conclusion: In this study knowledge of meat hygiene was mostly fair among respondents with a low level of meat hygiene practices and a high level of meat bacterial contamination. The study recommended training for meat handlers for hygiene maintenance, increased inspection of meat sold to the public and provision of standard facilities to ensure the maintenance of a good level of meat hygiene.

Key words: meat hygiene, butchers, meat handlers, abattoir, microbial profile

\section{Introduction}

Food borne diseases occur commonly in developing countries particularly in Africa because of the prevailing poor food handling and sanitation practices, obsolete food safety laws, weak regulatory systems, inadequate investment in safer equipment and poor education of food handlers. ${ }^{1}$ The World Health Organization (WHO) estimates that worldwide foodborne diseases are the cause of 600 million cases of ill-health and 420,000 deaths annually. Of these deaths, $30 \%$ are accounted for by children under 5 years of age. Globally, eating unsafe food is also estimated to 
result in 33 million years of healthy lives lost (YLL) yearly, and this number is believed to be an underestimation. ${ }^{2}$ More than 30 pathogens have been identified to be responsible including Norovirus, Salmonella, Campylobacter and E. coli among others. ${ }^{2}$ Estimates from the United States (US) Center for Disease Control (CDC) revealed that 48 million cases of illhealth, 128,000 hospitalizations, and 3,000 deaths in the US annually are from foodborne diseases. ${ }^{3}$ Africa has been shown to have the highest burden of food borne diseases per population. ${ }^{4}$ However, it is believed that food borne diseases are underestimated or underreported in developing countries as in Nigeria, where it is reported that 90,000 cases occur annually. ${ }^{5}$

Of the foods intended for humans, those of animal origin such as beef, pork, chicken and fish tend to be most hazardous and have been implicated in significant disease occurrence and mortality. ${ }^{6}$ An example cited was the report of beef being responsible for $7 \%$ of 1.7 million cases of foodborne disease that occurred in England and Wales between 1996 and $2000 .^{6}$ A meta-analysis of foodborne pathogens in selected African countries including Nigeria showed varying prevalences of bacterial contamination on raw meat.

An abattoir is "a premise approved and registered by the controlling authority for hygienic slaughtering and inspection of animals, processing, effective preservation and storage of meat products for human consumption". ${ }^{8}$ In abattoir operations, certain standards have to be met to provide basic environmental and operating conditions that are necessary for production of safe livestock products for food. Poor hygiene practices in abattoirs lead to the production, handling, sales and consumption of animal food products that constitute serious public health problems not limited to the butchers alone, but also to consumers and people in the immediate surroundings. ${ }^{9,10}$

Abattoir workers with poor hygiene practices along with a poor state of the abattoirs or meat processing plants and ineffective meat inspection service lead to increased risk of consuming unwholesome meat with a significant impact on the health and quality of life. ${ }^{11,12}$ The workers at the abattoir are at risk of occupational zoonosis such as anthrax, brucellosis and salmonellosis. Improper disposal of animal waste could cause pollution of water and air leading to unsanitary conditions of the environment and spread of diseases from breeding of flies at site of disposal.

This study sought to determine the knowledge and practices of meat hygiene amongst meat handlers (including butchers) in the government-run Jos abattoir of Plateau State. It also looked at the microbial meat profile of meat slaughtered and sold in the abattoir.

\section{Methods}

The study was a cross-sectional study conducted in the State owned abattoir of Plateau State Nigeria that is located in Giring ward of Jos South Local Government Area (LGA). It was established in 1975 for the purpose of inspection, slaughtering, processing and marketing of meat and meat products. ${ }^{13}$ Animals commonly slaughtered at this facility include sheep, goats, cows and pigs. The study population included adult meat handlers that operate within the abattoir. A meat handler was taken to be any individual that engages in receiving and/or storing, transporting and/or selling (wholesale and/or retail) of meat and/or poultry. It also included persons who may slaughter animals, dress their flesh, sell 
their meat or any combination of the three tasks.

The minimum sample size was calculated using the formula for cross-sectional studies and the proportion of $25.5 \%$ of those with good knowledge from a previous study with further adjustment for populations of less than 10,000 and a nonresponse of $10 \%{ }^{14,15}$ A total population sampling technique was used as a preliminary census conducted had shown that the study population was almost equivalent to the estimated sample size.

Data was collected using an interviewer administered questionnaire with sections on socio-demographic information, knowledge of meat hygiene, meat hygiene practices and factors affecting the practice of meat hygiene. Aspects of knowledge and practice that were assessed included hand washing, use of personal protective equipment, cleaning of the work environment, personal hygiene and work habits. Information on regulatory laws guiding the abattoir, training programmes and availability of water and sanitation facilities was also obtained.

Fresh meat samples were also collected from 6 different slaughter and sale sites (10 samples from each site), placed in sterile bottles and immediately transported in insulated ice-lined containers to the laboratory for analysis. This was done at the laboratory of Microbiology Department of the University of Jos using established standard methods. ${ }^{15}$ A gram of each sample was placed in $10 \mathrm{ml}$ of sterile water and serial dilutions of $10^{-1}, 10^{-2}$ were performed for bacterial isolation. Nutrient and MacConkey agar plates were inoculated with $200 \mathrm{ul}$ of each dilution and incubated at $37^{\circ} \mathrm{C}$ for 24 hours. Counts from the nutrient agar plates were noted as total viable counts while counts from MacConkey agar were noted as total coliform count. Bacterial isolates were identified based on morphological characteristics, Gram staining, biochemical tests such as urease test, citrate utilization, motility test, oxidase test and triple sugar iron agar. ${ }^{15}$

All data was collected, processed and analyzed using Epi-Info statistical software version 3.5.4. ${ }^{16}$ Knowledge and practice were scored and graded. For both knowledge and practice, they were graded based on percentages of the total attainable score; $80 \%$ and above for good, $50-79 \%$ for fair and less than $50 \%$ for poor. For knowledge, there was a total attainable score of 23 which were graded as good (18 - 23), fair $(11-17)$ and poor $(<11)$. For practice, there was a total attainable score of 24 graded as good (19-24), fair (12 - 18) and poor $(<12)$. A p-value of $\leq 0.05$ was considered statistically significant. Ethical clearance was obtained from the Jos University Teaching Hospital Human Research and Ethics Committee. Informed consent was obtained from each participant and permission was obtained from the management of the abattoir before commencement of the study.

\section{Results}

A total of 128 respondents were interviewed giving a response rate of $100 \%$. The mean age of respondents was $32.8 \pm 10.4$ years, those aged $21-40$ years formed $69.5 \%$ of the respondents. All were males. Half of them had completed secondary education. Fifty-eight $(58 \%)$ were married and $75 \%$ were from tribes indigenous to Plateau State. Ninety-nine percent (99\%) were Christians and 90\% had never had any form of training as shown in Table 1.

A summary of the responses to the knowledge assessment questions is shown in Table 2. Fifty-one (40.2\%) of them were aware of what meat hygiene was, but only 
$31(24.2 \%)$ could adequately explain what it meant. One hundred and twenty (93.7\%) of them stated that it was important for meat to be handled safely and all agreed that they have a role in ensuring that meat is kept hygienic. Respondents agreed that hand washing before meat handling; 124 $(96.8 \%)$ and after using the toilet; 125 (97.7\%), proper cleaning and handling of instruments and utensils; 121 (94.5\%), daily washing of the work area; 127 $(99.2 \%)$ and livestock inspection; 127 $(99.2 \%)$ would reduce the risk of meat contamination. Respondents agreed that meat should not be handled by persons with skin infections; $89(69.5 \%)$, diarrhoea; 71 (55.5\%) or cough; 87 (68\%). Seventy nine $(62 \%)$ stated that the use of gloves reduces the risk of meat contamination, $68(53 \%)$ agreed that it is safe to handle meat and money together, while $56(44 \%)$ felt eating and drinking in the work place exposes you to infection. A hundred and seventeen (91.4\%) stated that regular medical checks will help reduce disease transmission, $127(99 \%)$ stated that livestock should be inspected before slaughter and that facilities should be inspected regularly; 125 (98\%). It was agreed by $101(78.9 \%)$ that meat should be refrigerated after slaughter to prevent microbial growth on the meat. Knowledge of meat hygiene when graded found 50 $(39.1 \%)$ were good, $71(55.5 \%)$ were fair and $7(5.5 \%)$ were poor with a mean knowledge score of $16.4 \pm 3.1$. Knowledge was found to be statistically significantly associated with level of education $\left(\mathrm{x}^{2}=\right.$ $31.49, \mathrm{df}=6, \mathrm{p}<0.001)$ as seen in Table 3 .

Good practices that were prevalent amongst them included daily cleaning of work surfaces; 115 (89.8\%), daily washing of instruments; 115 (89.8\%), washing of hands before meat handling; 127 (99.2\%), avoiding work when ill; 109 (85.2\%), keeping their fingernails short; 115
$(89.8 \%)$ and refrigerating of leftover meat; $128(100 \%)$. The meat on the day of interview was said to have been inspected by $126(98.4 \%)$ of respondents and 127 $(99.2 \%)$ were selling meat of animals slaughtered on that day though 110 $(85.9 \%)$ said that in the 2 weeks prior to the study, meat that did not pass inspection were still slaughtered and sold. Poor practices identified amongst them included infrequent washing of aprons; 91 (71.1\%) non-use of gloves; $119(93.7 \%)$ and handling of meat when injured; 86 (67.7\%). Most; 119 (92\%) would cover their mouths when coughing over meat but $70(58.8 \%)$ would use their palms to cover their mouths. Most animals were slaughtered on the floor, $126(98.4 \%)$ and $124(96.8 \%)$ butchers would also leave the meat exposed when on display on the tables. (Table 4)

The practices of respondents were found to be good in $11(8.6 \%)$ and fair in 117 $(91.4 \%)$ persons. None was adjudged to be poor. The mean practice score was $16.5 \pm$ 1.7. Practices were found to be significantly associated with level of education $\left(\mathrm{x}^{2}=8.36, \mathrm{p}=0.039\right)$ as shown in Table 3. No statistically significant relationship was found between previous training and knowledge, previous training and practice and between knowledge and practice (Table 3 ). Information regarding the work conditions and environment of the abattoir was obtained from the respondents. All (100\%) respondents stated that they were aware that there are laws guiding the operation of the abattoir but $126(98.4 \%)$ agreed that these laws are ineffective. Sources of water included municipal tap; 118 (92.2\%), well; 52 $(40.6 \%)$, stream; 2 (1.6\%) and rain water; 2 $(1.6 \%)$. Hand washing facilities were stated to be available by $67(52.3 \%)$ of respondents and $107(83.6 \%)$ stated that toilet facilities were available. Only 5 
(3.9\%) said that personal protective equipment were made available to them. Regarding the frequency of hygiene inspection visits to the abattoir, $71(55.5 \%)$ respondents said the visits were done monthly, every 2 months (10;7.8\%), every $3-6$ months $(9 ; 7 \%)$, > 6months $(22 ; 1.7 \%)$ and never (7\%).

Microbial test results of meat samples are shown in tables 5 and 6 . All meat samples had high microbial contamination with mean total coliform count of $2.5 \times 10^{3} \pm 3.4$ $\mathrm{cfu} / \mathrm{ml}$. The microbe found on all meat samples was E. coli with Pseudomonas spp. found on all except on one site. Other organisms that were isolated were Enterobacterspp, Citrobacter, Salmonella typhi and paratyphi.

Recommendations made by respondents on how to improve the abattoir included complete renovation of the abattoir; 68 $(53.5 \%)$, provision of clean water all year round; 23 (18.1\%), better electricity supply; $13(10.2 \%)$ and privatization of the abattoir; 5 (3.9\%).

Table 1: Socio-demographic profile of respondents

\begin{tabular}{|c|c|c|}
\hline Variable & Frequency $(n=128)$ & Percent (\%) \\
\hline \multicolumn{3}{|l|}{ Age group (years) } \\
\hline $18-20$ & 12 & 9.4 \\
\hline $21-30$ & 48 & 37.5 \\
\hline $31-40$ & 41 & 32.0 \\
\hline $41-50$ & 21 & 16.4 \\
\hline $51-60$ & 4 & 3.1 \\
\hline$>60$ & 2 & 1.6 \\
\hline \multicolumn{3}{|l|}{ Highest level of education } \\
\hline None & 15 & 11.7 \\
\hline Primary & 45 & 35.2 \\
\hline Secondary & 65 & 50.8 \\
\hline Tertiary & 3 & 2.3 \\
\hline \multicolumn{3}{|l|}{ Marital status } \\
\hline Married & 74 & 57.8 \\
\hline Single & 53 & 41.4 \\
\hline Widowed & 1 & 0.8 \\
\hline \multicolumn{3}{|l|}{ Tribe } \\
\hline Indigenous Plateau tribes & 95 & 74.2 \\
\hline Non-indigenous tribes & 33 & 25.8 \\
\hline \multicolumn{3}{|l|}{ Religion } \\
\hline Christianity & 127 & 99.2 \\
\hline Islam & 1 & 0.8 \\
\hline \multicolumn{3}{|l|}{$\begin{array}{l}\text { Received meat hygiene } \\
\text { training }\end{array}$} \\
\hline Yes & 13 & 10.2 \\
\hline No & 115 & 89.8 \\
\hline
\end{tabular}


Table 2: Responses from assessment of knowledge of meat hygiene

\begin{tabular}{|c|c|c|}
\hline \multirow[b]{2}{*}{ Statement } & \multicolumn{2}{|c|}{ Response $(n=128)$} \\
\hline & $\begin{array}{c}\text { Yes } \\
\text { Freq }(\%)\end{array}$ & $\begin{array}{c}\text { No } \\
\text { Freq }(\%)\end{array}$ \\
\hline Ever h eard of meat hygiene & $51(40.2)$ & $76(59.8)$ \\
\hline Adequate explained what meat hygiene is & $31(24.2)$ & $97(75.8)$ \\
\hline Safe food handling is an important part of my job & $120(93.7)$ & $8(6.3)$ \\
\hline $\begin{array}{l}\text { Hand washing before starting work reduces } \\
\text { contamination of meat }\end{array}$ & $124(96.8)$ & $4(3.1)$ \\
\hline $\begin{array}{l}\text { Hand washing after using the toilet reduces } \\
\text { contamination of meat }\end{array}$ & $125(97.7)$ & $3(2.3)$ \\
\hline $\begin{array}{l}\text { Proper cleaning and handling of instruments reduce } \\
\text { the risk of food contamination }\end{array}$ & $121(94.5)$ & $7(5.5)$ \\
\hline Daily cleaning of work slabs is important & $127(99.2)$ & $1(0.8)$ \\
\hline Using gloves reduces risk of contamination & $79(61.7)$ & $49(38.3)$ \\
\hline $\begin{array}{l}\text { Livestock must be inspected by veterinary doctors } \\
\text { before slaughtering }\end{array}$ & $127(99.2)$ & $1(0.8)$ \\
\hline $\begin{array}{l}\text { It is important to quickly refrigerate slaughtered meat } \\
\text { You shoul } \mathrm{d} \text { not handle meat if you have }\end{array}$ & $101(78.9)$ & $27(21.1)$ \\
\hline Cough & $87(68.0)$ & $41(32.0)$ \\
\hline Diarrhea & $71(55.5)$ & $57(44.5)$ \\
\hline Skin infection & $89(69.5)$ & $39(30.5)$ \\
\hline $\begin{array}{l}\text { Eating and drinking in the work place exposes you to } \\
\text { infection }\end{array}$ & $56(43.8)$ & $72(56.3)$ \\
\hline It is okay to slaughter dead 1 ivestock & $5(3.9)$ & $123(96.1)$ \\
\hline Handling meat and money is okay & $68(53.0)$ & $60(46.9)$ \\
\hline The best action to take when you get a cut at work is & & \\
\hline Cover cut and continue work & $42(32.8)$ & - \\
\hline Seek first aid before resuming & $73(57.0)$ & - \\
\hline Wash cut and continue work & $13(10.2)$ & - \\
\hline $\begin{array}{l}\text { Regular medical check -ups prevent spread of } \\
\text { foodborne diseases by workers }\end{array}$ & $117(91.4)$ & $11(8.6)$ \\
\hline
\end{tabular}


Table 3: Relationship of respondents' knowledge and practice grade with socio-demographic characteristics

\begin{tabular}{|c|c|c|c|c|c|c|c|}
\hline \multirow[b]{2}{*}{ Age group } & \multicolumn{3}{|c|}{ Knowledge Grade } & \multirow{2}{*}{$\begin{array}{c}\text { p- } \\
\text { value }\end{array}$} & \multicolumn{2}{|c|}{ Practice Grade } & \multirow{2}{*}{$\begin{array}{l}\text { P- } \\
\text { value }\end{array}$} \\
\hline & Poor & Fair & Good & & Fair & Good & \\
\hline .. & $57(44.5)$ & $39(30.5)$ & $5(3.9)$ & 0.843 & $92(71.9)$ & $9(7.0)$ & 0.804 \\
\hline$>40$ & $14(10.9)$ & $11(8.6)$ & $2(1.6)$ & & $25(19.5)$ & $2(1.6)$ & \\
\hline \multicolumn{8}{|l|}{$\begin{array}{l}\text { Highest level } \\
\text { of education }\end{array}$} \\
\hline None & $5(3.9)$ & $8(6.2)$ & $2(1.6)$ & & $15(11.7)$ & $0(0.0)$ & \\
\hline Primary & $1(0.8)$ & $30(23.4)$ & $14(10.9)$ & $<0.001$ & $44(34.3)$ & $1(0.8)$ & 0.039 \\
\hline Secondary & $1(0.8)$ & $32(25)$ & $32(25)$ & & $56(43.8)$ & $9(7.0)$ & \\
\hline Tertiary & $0(0.0)$ & $1(0.8)$ & $2(1.6)$ & & $2(1.6)$ & $1(0.8)$ & \\
\hline \multicolumn{8}{|l|}{ Tribe } \\
\hline Indigenous & $7(5.4)$ & $50(39.1)$ & $36(28.1)$ & 0.350 & $86(67.2)$ & $9(7.0)$ & 0.548 \\
\hline $\begin{array}{r}\text { Non- } \\
\text { indigenous }\end{array}$ & $0(0.0)$ & $19(14.8)$ & $14(10.9)$ & & $31(24.2)$ & $2(1.6)$ & \\
\hline \multicolumn{8}{|l|}{$\begin{array}{l}\text { Received } \\
\text { training }\end{array}$} \\
\hline No & $7(5.4)$ & $63(49.2)$ & $45(35.1)$ & 0.641 & $106(82.2)$ & $9(7.0)$ & \\
\hline Yes & $0(0.0)$ & $8(6.3)$ & $5(4.0)$ & & $11(8.6)$ & $2(1.6)$ & 0.196 \\
\hline \multicolumn{8}{|l|}{$\begin{array}{l}\text { Knowledge } \\
\text { grade }\end{array}$} \\
\hline Poor & - & - & - & & $7(5.5)$ & $0(0.0)$ & \\
\hline Fair & - & - & - & & $67(52.3)$ & $4(3.1)$ & 0.191 \\
\hline Good & - & - & - & & $43(33.6)$ & $7(5.5)$ & \\
\hline
\end{tabular}


Table 4: Meat hygiene practices of respondents

\begin{tabular}{|c|c|c|}
\hline V ariable & Frequency & Percent $(\%)$ \\
\hline \multicolumn{3}{|l|}{ Water sources (multiple response) } \\
\hline Municipal supply & 118 & 92.2 \\
\hline Well & 52 & 40.6 \\
\hline Rain & 2 & 1.6 \\
\hline Hand washing before handling meat & 127 & 99.2 \\
\hline Hand washing after use of the toilet & 127 & 99.2 \\
\hline \multicolumn{3}{|l|}{ Frequency of washing instruments } \\
\hline Daily & 115 & 89.8 \\
\hline Twice daily & 1 & 0.8 \\
\hline Twice weekly & 1 & 0.8 \\
\hline Others (after each use, not at all, when needed) & 11 & 8.6 \\
\hline Keeps nails short & 115 & 89.8 \\
\hline Avoid work when ill & 109 & 85.2 \\
\hline Handling of meat when injured & 86 & 67.7 \\
\hline Storage of leftover meat by refrigeration & 128 & 100.0 \\
\hline Wearing of gloves when handling meat & 8 & 6.3 \\
\hline \multicolumn{3}{|l|}{ Frequency of washing aprons/overalls } \\
\hline Daily & 37 & 29.1 \\
\hline Once a week & 30 & 23.6 \\
\hline Twice weekly & 13 & 10.2 \\
\hline Thrice weekly & 21 & 16.5 \\
\hline Only when adjudged dirty & 18 & 14.2 \\
\hline No fixed time & 8 & 6.3 \\
\hline Covering of nose and mouth when coughing & 116 & 90.6 \\
\hline \multicolumn{3}{|l|}{ Item used to cover when coughing } \\
\hline Palms & 70 & 58.8 \\
\hline Piece of cloth & 49 & 41.2 \\
\hline Meat of present day inspected & 126 & 98.4 \\
\hline \multicolumn{3}{|l|}{ Location of slaughter of meat for present day } \\
\hline Floor/ground & 112 & 89.6 \\
\hline Slaughter slab & 13 & 10.4 \\
\hline Meat covered while on table & 4 & 3.1 \\
\hline \multicolumn{3}{|l|}{ What is done with unused parts } \\
\hline Sold & 99 & 77.3 \\
\hline Burnt & 15 & 11.7 \\
\hline Dumped & 12 & 9.4 \\
\hline Flushed & 2 & 1.6 \\
\hline \multicolumn{3}{|l|}{$\begin{array}{l}\text { What was done with animals rejected for slaughter } \\
\text { in the last } 2 \text { weeks }\end{array}$} \\
\hline Slaughtered & 110 & 85.9 \\
\hline Treated & 18 & 14.1 \\
\hline
\end{tabular}


Table 5: Microbial quality of fresh beef based on different slaughter sites (mean \pm standard deviation)

\begin{tabular}{llll}
\hline Slaughter sites & No. sampled & $\begin{array}{l}\text { Total viable count } \\
\mathbf{( c f u / m l )}\end{array}$ & $\begin{array}{l}\text { Total coliform count } \\
\mathbf{( c f u} / \mathbf{m l})\end{array}$ \\
Site $\mathbf{1}$ & 10 & $2.1 \times 10^{3} \pm 1.5 \times 10^{3}$ & $3.3 \times 10^{2} \pm 1.2 \times 10^{2}$ \\
Site 2 & 10 & $3.0 \times 10^{3} \pm 1.1 \times 10^{2}$ & $1.2 \times 10^{3} \pm 7.1 \times 10^{2}$ \\
Site 3 & 10 & $1.2 \times 10^{3} \pm 5.2 \times 10$ & $1.3 \times 10^{2} \pm 10.0$ \\
Site 4 & 10 & $3.0 \times 10^{3} \pm 3.2 \times 10^{2}$ & $1.6 \times 10^{3} \pm 5.3 \times 10^{2}$ \\
Site 5 & 10 & $4.6 \times 10^{3} \pm 1.9 \times 10^{3}$ & $5.8 \times 10^{2} \pm 5.5 \times 10^{2}$ \\
Site 6 & 10 & $4.0 \times 10^{3} \pm 8.4 \times 10^{2}$ & $1.6 \times 10^{3} \pm 1.2 \times 10^{3}$ \\
\hline
\end{tabular}

Table 6: Distribution of bacterial isolates in relation to slaughter sites

\begin{tabular}{|c|c|c|c|c|c|c|c|}
\hline $\begin{array}{l}\text { Slaughter } \\
\text { sites }\end{array}$ & $\begin{array}{l}\text { No. } \\
\text { sampled }\end{array}$ & E.coli & $\begin{array}{l}\text { Pseudomonas } \\
\text { spp }\end{array}$ & $\begin{array}{l}\text { Enterobacter } \\
\text { spp }\end{array}$ & S.typhi & S.paratyphi A. & $\begin{array}{l}\text { Citrobacter } \\
\text { spp. }\end{array}$ \\
\hline Site 1 & 10 & $3(30.0)$ & $0(0.0)$ & $6(60.0)$ & $0(0.0)$ & $0(0.0)$ & $0(0.0)$ \\
\hline Site 2 & 10 & $6(60.0)$ & $4(40.0)$ & $0(0.0)$ & $0(0.0)$ & $2(2.0)$ & $0(0.0)$ \\
\hline Site 3 & 10 & $3(30.0)$ & $6(60.0)$ & $0(0.0)$ & $0(0.0)$ & $0(0.0)$ & $0(0.0)$ \\
\hline Site 4 & 10 & $4(40.0)$ & $2(20.0)$ & $0(0.0)$ & $4(40.0)$ & $0(0.0)$ & $0(0.0)$ \\
\hline Site 5 & 10 & $6(60.0)$ & $4(40.0)$ & $0(0.0)$ & $0(0.0)$ & $0(0.0)$ & $0(0.0)$ \\
\hline Site 6 & 10 & $4(40.0)$ & $2(20.0)$ & $0(0.0)$ & $0(0.0)$ & $2(20.0)$ & $1(10.0)$ \\
\hline Total & 60 & $26(43.3)$ & $18(30.0)$ & $6(10.0)$ & $4(6.7)$ & $4(6.7)$ & $1(1.7)$ \\
\hline
\end{tabular}

\section{Discussion}

All the respondents in the study were male. This is not surprising as it is typically regarded as a job for males especially in this environment. The young age and low educational status is a finding consistent with other studies conducted among meat handlers in abattoirs in this country. ${ }^{17,18}$ It is a job that requires physical strength and no formal training hence can easily be taken up as a profession by those who are young and are not able to further their education.

Meat is a highly nutritious food item providing protein, fat and minerals to humans. In its raw form, it is a good substrate for the multiplication and growth of microorganisms. Butchers serve as a link for consumers to meat that is slaughtered and prepared for sale. They are a key point in maintaining the hygiene of meat sold to consumers. In this study less than $30 \%$ were aware of what the term meat hygiene meant. Notwithstanding, more than half had a fair knowledge of what is required for meat hygiene. Their knowledge regarding cleaning instruments, work slabs and hand washing were high but other aspects of hygiene such as use of PPE, cough etiquette, illness and injury management during work were lower. This finding was quite similar to that in a study conducted in Andhra Pradesh. ${ }^{19}$ It has been found in other studies that the knowledge of hygiene among butchers is usually poor to fair. ${ }^{18,20,21}$ Knowledge was found to be statistically significantly related to level of education. This finding was also demonstrated in a study where they found increasing levels of knowledge with increasing level of education among meat handlers. ${ }^{22}$ Lack of training among meat handlers has been reported in Ethiopia and Nigeria ${ }^{18,23,24}$ and has been noted to influence both knowledge and practice among butchers and meat 
handlers. In contrast, most of the respondents in this study had no training but that was not found to be associated with either knowledge or practice no association could be established.

The practices found among most of the study population was found to be fair. It was also found to have a statistically significant relationship with level of education. This is consistent with findings in other studies conducted in Nigeria and other African countries. ${ }^{17,21,25}$ However quite a number of their practices had implications for the meat they were handling. Less than $30 \%$ would wash their aprons/overalls daily, most would not use gloves, most would use their palm to cover their mouths when coughing and most would still handle meat while having injuries. All these give room for contamination and cross contamination of meat and endangers not only consumers but the meat handlers themselves. The animals were inspected infrequently, found to be slaughtered on the floor, with mixed sources of water in use and exposure of meat during sale. A worrisome practice is the sale of meat that had been condemned, a practice that would endanger the lives of consumers from zoonotic infections. This supports the finding of poor inspection practices and enforcement of rules and regulations as documented in a study conducted in Benue State, Nigeria that found poor assessment of livestock and inspection issues in several abattoirs. ${ }^{26}$ The reported conditions of the abattoir showed less than adequate accessibility to hand washing and toilet facilities, lack of PPE and ineffective laws guiding its operations. A case report on the Jos abattoir also made observations on these conditions and poor practices that were prevalent there. ${ }^{13}$ These same practices are prevalent in other abattoirs around the country. ${ }^{27,28,29} \mathrm{~A}$ limitation of this study was not being able to verify all the practices as some were not being conducted at that time and respondents could have provided inaccurate responses to the questions asked.

The results of the microbial analysis on meat samples showed high levels of microbial contamination. These findings are comparable with several studies where poor hygienic practices were also documented. ${ }^{23,30,31}$ In contrast, microbial loads assessed in European abattoirs where hygiene standards are much higher showed undetectable levels of contamination. ${ }^{32}$ Though direct links between hygiene and microbial loads were not established in this study, it is evident that when compared with the finding in the European abattoirs, improved hygiene practices would lead to lower contaminant levels. It is also documented that contamination levels up to $10^{5} \mathrm{cfu} / 100 \mathrm{ml}$ indicate that the meat was slaughtered under unsatisfactory hygienic conditions and the levels in this study are extremely higher than that threshold. The most prevalent microbe isolated were the coliforms E. coli and Pseudomonas. Coliforms are indicative of faecal contamination and repeatedly are identified when meat is being assessed for contamination by microorganisms. ${ }^{23,31,33,34}$ The findings in this study of fair levels of knowledge and practice of meat hygiene less than ideal conditions in the abattoir and the high level of microbial growth found on the meat samples are a matter of concern. Being a government owned facility, the responsibility falls on them to fully train meat handlers operating on the premises and provide facilities that protect the hygiene of the meat slaughtered and sold in the abattoir. There should also be an increased level of supervision by the relevant authorities. This will serve to reduce exposure of consumers to infectious diseases potentially present on the meat. 


\section{Conflict of interest}

The authors declare that there is no conflict of interest in the production of this manuscript.

\section{Acknowledgement}

The authors wish to acknowledge the assistance of Buma FP, Akinsanmi SO, Boyi OP in the administration of the questionnaires.

\section{References}

1. Subratty AH, Gurib FBH. Consumers' concern about the meat product quality offered for sale in Mauritius. Nutrit Food Sci. 2003;33(2):80-83.

2. World Health Organization. Estimating the burden of foodborne diseases. https://www.who.int/activities/estimat ing-the-burden-of-foodbornediseases. Accessed 14 Dec 2019.

3. Centers for Disease Control and Prevention. Estimates of Foodborne Illness in the United States. https://www.cdc.gov/foodborneburden/es timates-overview.html. Accessed 14 Dec 2019.

4. World Health Organization. WHO estimates of the global burden of foodborne diseases: foodborne disease burden epidemiology reference group 2007-2015. WHO Library Cataloguing-in-Publication Data; 2015. pp. 1-252.

5. Odeyemi OA. Public health implications of microbial food safety and foodborne diseases in developing countries. Food Nutr Res. 2016;60:29819. doi:10.3402/fnr.v60.29819.

6. Heredia N, García S. Animals as sources of food-borne pathogens: a review. AnimNutr. 2018;4(3):250-255. doi:10.1016/j.aninu.2018.04.006.
7. Paudyal N, Anihouvi V, Hounhouigan J, Matsheka MI, Sekwati-Monang B, Amoa-Awua W et al. Prevalence of foodborne pathogens in food from selected African countries - a metaanalysis. International Journal of Food Microbiology. 2017; 249:35-43. Available at: https://doi.org/10.1016/j.ijfoodmicro. 2017.03.002.

8. Adonu RE, Dzokoto L, Salifu SI. Sanitary and hygiene conditions of slaughterhouses and its effect on the health of residents (a case study of Amasaman slaughterhouse in the Ga West Municipality, Ghana). Food Science and Quality Management. 2017; 65. ISSN 2224-6088 (Paper) ISSN 2225-0557 (Online).

9. Ngbede EO, Raji MA, Kwanashie CN, Okolocha EC, Gugong VT, Hambolu SE. Serological prevalence of leptospirosis in cattle slaughtered in the Zango abattoir in Zaria, Kaduna State, Nigeria. Vet Ital. 2012; 48(2):179-84.

10. Cook EA, de Glanville WA, Thomas LF, Kariuki S, Bronsvoort BM, Fèvre EM. Working conditions and public health risks in slaughterhouses in western Kenya. BMC Public Health. 2017; 17(1):14. doi:10.1186/s12889016-3923-y.

11. Abdullahi A, Hassan A, Kadarman N, Saleh A, Baraya YS, Lua PL. Food safety knowledge, attitude, and practice toward compliance with abattoir laws among the abattoir workers in Malaysia. International Journal of General Medicine 2016; 9. doi: https://doi.org/10.2147/IJGM.S98436. Available at: https://www.dovepress.com/foodsafety-knowledge-attitude-andpractice-toward-compliance-withaba-peer-reviewed-fulltext-article- 
IJGM

12. Fasanmi O G, Makinde GEO, Popoola MA, Fasina OF, Matere J, Kehinde OO, et al. Potential risk factors associated with carcass contamination in slaughterhouse operations and hygiene in Oyo state, Nigeria. International Journal of Livestock Production. 2018; 9(8), 211-220. doi: https://doi.org/10.5897/IJLP2018.0491. Available at: https://academicjournals.org/journal/I JLP/article-abstract/0BA638057796.

13. Tekki I, Nwankpa ND, Dashe Y, Owolodun O.A, Elisha IL. Abattoir management: a case report of a local abattoir in Jos South, Plateau State, Nigeria. Vom Journal of Veterinary Science. 2012; 9: 40 - 46.

14. AraoyeOA. Sample size determination. In: Research methodology with statistics for health and social sciences. Nathadex publishers, Ilorin; 2003. p. 115-122.

15. Holt JG, Kreig NR, Sneath PHA, and Staley JT. Bergey's Manual of Determinative Bacteriology. The William and Wilkins Co., Baltimore, Md, USA, 9th edition, 1994.

16. Centers for Disease Control and Prevention. EpiInfo ${ }^{\mathrm{TM}}$ 3.5.4. Epi Info previous versions. 2012. Available at: https://www.cdc.gov/epiinfo/support/do wnloads/prevversions.html.

17. Junaidu YM, Bhagavandas M, Yusha'u U. Study of knowledge, attitude and practices regarding hygiene among abattoir workers in Kano state metropolitan, Nigeria. International Journal of Science and Research (IJSR). 2015; 4(1).

18. Enem SI. An appraisal of the knowledge, attitude and practices (KAP) of meat handlers on their personal hygiene in Gwagwalada municipal abattoir, Abuja, Nigeria.
International Journal of Development Research. 2017; 07(12):17807-17811. Available at: http://www.journalijdr.com.

19. Venkata SRC, Sujitha B, Maheswara $\mathrm{RD}$, Vani S. Awareness and practices followed by the butchers in hygienic meat production chain in YSR Kadapa district of Andhra Pradesh. The Pharma Innovation Journal 2019; 8(10): 140-145.

20. Ansari-Lari M, Soodbakhsh S, Lakzadeh L. Knowledge, attitudes and practices of workers on food hygienic practices in meat processing plants in Fars, Iran. Food Control. 2010; 21: 260-263.

21. Tegegne HA, Phyo HWW. Food safety knowledge, attitude and practices of meat handler in abattoir and retail meat shops of Jigjiga Town, Ethiopia. J Prev Med Hyg. 2017; 58(4):E320-E327. doi:10.15167/24214248/jpmh2017.58.4.737.

22. Calin J, Ionut $G$, Knowledge of food safety and hygiene and personal hygiene practices among meat handlers operating in western Romania. Food Control. 2014; 42: E214 - E219.

23. Haileselassie M, Taddele H, Adhana K, Kalayou S. Food safety knowledge and practices of abattoir and butchery shops and the microbial profile of meat in Mekelle city, Ethiopia. Asian Pac J Trop Biomed. 2013; 3(5):407-412. doi:10.1016/S22211691(13)60085-4.

24. Alhaji NB, Baiwa M. Factors affecting workers' delivery of good hygienic and sanitary operations in slaughterhouses in north-central Nigeria. Sokoto Journal of Veterinary Sciences. 2015; 13(1): 29-37.

Available at: http://dx.doi.org/10.4314/sokjvs.v13i 
1.5 .

25. Wambui J, Karuri E, Lamuka P, Matofari J. Good hygiene practices among meat handlers in small and medium enterprise slaughterhouses in Kenya. Food Control. 2017; 81:3439.

26. Kundu S, Idusiye M and TernengeApaa. Assessment of livestock slaughtered for food and meat inspection issues in selected abattoirs in Benue State, Nigeria. Cogent Food \& Agriculture 2015: 1:1. doi: $10.1080 / 23311932.2015 .1106386$

27. Olawuni PO, Daramola OP and Soumah M. Environmental implications of abattoir waste generation and management in developing countries: the Case of Lagos State Abattoir in Agege, Nigeria. Greener Journal of Social Sciences. 2017; 7(2): 007-014. DOI: http://doi.org/10.15580/GJSS.2017.2. 050715068.

28. Douglas KE, Ovua A, Orji C, Sapira B. Health implications of sanitation in a public abattoir in Port Harcourt, Nigeria. Nigerian Health Journal. 2013; 13(2):91 - 95.

29. Adeolu AT, Opasola AO, Salami OO, Iyanda AY, Omenta RC. Sanitary status and compliance with the standard slaughter practices in Karu Abattoir Abuja Municipal Area Council of the FCT, Nigeria. International Journal of Current Innovations in Advanced Research. 2019; 2(2):1-14.

30. Ukut OE, Okonko IO, Ikpoh IS,
Nkang AO, Udeze AO, Babalola TA, Mejeha OK, Fajobi EA. Assessment of bacteriological quality of fresh meats sold in Calabar metropolis, Nigeria. EJEAFChe. 2010; 9(1):89 100 .

31. Bersisa A, Tulu D, Negera C. Investigation of bacteriological quality of meat from abattoir and butcher shops in Bishoftu, Central Ethiopia. International Journal of Microbiology. 2019; 8 pages.

Available at: https://doi.org/10.1155/2019/6416803. Last accessed $20 \mathrm{Feb} 2020$.

32. Alvseikea O, Røssvolla E, Røtteruda O, Nesbakkenb T, Skjerveb E, Prietoc $\mathrm{M}$ et al. Slaughter hygiene in European cattle and sheep abattoirs assessed by microbiological testing and Hygiene Performance Rating. Food Control 101. 2019; 233-240. doi: https://doi.org/10.1016/j.foodcont.201 9.01 .033

33. Bhandare S, Paturkar AM, Waskar VS, Zende RJ. Prevalence of microorganisms of hygienic interest in an organized abattoir in Mumbai, India. J Infect DevCtries. 2010; 4(7):454-458.

34. Fasanmi GO, Olukole SG, Kehinde OO. Microbial studies of table scrapings from meat stalls in Ibadan metropolis, Nigeria: implications on meat hygiene. Afr. J. Biotechnol. 2010; 9(21):3158-3162. Available at: http://www.academicjournals.org/AJ B. 